Nghiên cứu LUX-Lung 3 các tác dung phụ ghi nhận ở nhóm Pem/cis gồm: nôn các mức độ: 42,3\%; độ 3 và 4: 2,6\%; mệt mỏi các mức độ: $46,8 \%$; tiểu chảy độ 1 và 2 là $15,3 \%$.

Nghiên cứu của Schuette W.H ghi nhận buồn nôn chỉ có 3 (4.6\%) bệnh nhân

\section{KẾT LUÂNN}

5.1. Kểi quả điêu trị. Tỷ lệ đáp ứng một phần 37,5\%; bệnh ổn định 46,4\%. Lợi ích lâm sàng sau 06 chu kì 83,9\%.

5.2. Tác dụng phụ của thuốc. Tác dụng phụ trên hệ tạo huyết mức độ 3 và 4 gặp: hạ bạch cầu 10,7\%; thiếu máu $7,1 \%$; hạ tiểu cầu $5,3 \%$. Tác dụng phụ ngoài hệ tạo huyết mức độ 3 và 4 chỉ gặp nôn: $10,7 \%$.

Như vâyy phác đồ Pemetrexed - Cisplatin có hiệu quả và dung nạp rất tốt trên các bệnh nhân ung thư phổi giai đoạn muộn.

\section{TÀI LIÊU THAM KHẢO}

1. GLOBOCAN (2012), "Etimated Cancer Incidence, Mortality and Prevalance Worldwide in 2012".

2. Bùi Diệu, Nguyễn Bá Đức, Trân Văn Thuấn, Nguyến Thị Hoài Nga và cs (2012), "Gánh nậng bệnh ung thư và chiến lược phòng chống ung thư quốc gia đến năm 2020", Tạp chí Ung thư hoc Viêt Nam, số 1 tr $13-19$.

3. Nguyển Bá Đức (2007), "Chẩn đoán và điều trị bệnh ung thu", Nhà xuất bản y hoc tr. $176-187$.

4. Van Houtte $P$, McDonald $S$, Yuang-Chi Chang A, Salazar OM. Lung cancer 8 ed. In: Rubin P, Williams JP, editors. Clinical oncology: a multidisciplinary approach for physicians and students. Philadelphia, PA: WB Saunders Company; 2001

5. Schiller, J.H., et al., Comparison of four chemotherapy regimens for advanced non-small-cell lung cancer. N Engl J Med, 2002. 346(2): p. 92-8.

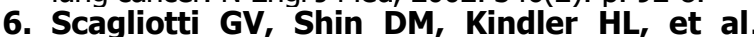
Phase II study of pemetrexed with and without folic acid and vitamin B 12 as front-line therapy in malignant pleural mesothelioma. J Clin Oncol 2003; 21: $1556-61$

7. Shepherd FA, Dancey J, Arnold A, et al. Phase II study of pemetrexed disodium, a multitargeted antifolate, and cisplatin as first-line therapy in patients with advanced non-small cell lung carcinoma. Cancer 2001 ; 92: $595-600$.

8. Goldman DI, Zhao R. Molecular, biochemical, and cellular pharmacology of pemetrexed. Semin Oncol 2002;29:3-17

9. Zinner RG, Obasaju CK, Fossella FV, et al. A phase II trial of ALIMTA plus carboplatin (AC) in patients (pts) with advanced non-small-cell lung cancer (NSCLC) [abstract P-522]. Lung Cancer 2003 ; 41: S223

\title{
NGHIÊN CỨU ĐĂC ĐIỂM LÂM SÀNG, CÂN LÂM SÀNG CỦA UNG THƯ BÀNG QUANG TẠI BỆNH VIỆN K
}

\section{TÓM TẮT}

Mục tiêu: Nghiên cứu đặc điểm lâm sàng, cận lâm sàng của bệnh nhân ung thư bàng quang. Đối tượng và phướng pháp nghiên cứu: Nghiển cứu can thiệp lâm sàng không đối chứng tiến hành trên các bệnh nhân ung thư biểu mổ bàng quang đã được phẩu thuật cắt bàng quang toàn bộ và chuyển lưu dòng tiểu tại Bệnh viện $K$. Kết quả: Đa số các bênh nhân là nam giới trong độ tuổi 50-70; 14 bệnh nhân từng có tiền sử mổ nội soi cắt u và mổ cắt bán phần bàng quang. 77,4\% bệnh nhân được phấu thuật nội soi chẩn đoán giai đoạn trước mổ.Bệnh nhân nghiện thuốc lá $(80,6 \%)$ và nghiên rươu $(64,5 \%)$. Đái máu là triệu chứng lâm sàng chủ yếu $(80,6 \%)$ Tồng phân tích nước tiểu: $90,3 \%$ hồng câu niêu, $71 \%$ có bach cầu niệu, $71 \%$ có protein niệu. Bệnh nhân có tổn thương u đớn độc 61,3\%; kích thước u từ 3-5 cm. Vị trí u hay

\section{*Bênh viện K}

Chiu trách nhiệm chính: Phạm Văn Bình

Email: binhva@yahoo.fr

Ngày nhận bài: 22.01.2021

Ngày phản biên khoa học: 19.3.2021

Ngày duyệt bài: 26.3.2021
Phạm Văn Bình*, Đỗ Anh Tuấn*

găp nhiêu vị trí $29 \%$; thành bên và thành sau tương đương nhau 22,6\%; thành trước $16,1 \%$ và có 3 trường hợp $9,7 \%$ u chèn ép lỗ niệu quản gây giãn thân. Gia đoan U: T2 58,2\%, T3 chiếm $19,4 \%$ và T4 chiếm $6,5 \%$. Bệnh nhân giai đoạn II $77,4 \%$. Giải phẫu bênh ung thư biểu mô chuyển tiếp 96,8\%. Kết luân: Ung thư bàng quang hay gặp ở nam hơn ở nữ, hút thuốc lá và nghiện rượu là yếu tố nguy cơ cao, đái máu là dấu hiệu lâm sàng phổ biến, giải phẫu bệnh chủ yếu là ung thư biểu mô chuyển tiếp

Tư khóa: Ung thư bàng quang.

\section{SUMMARY}

STUDY OF CLINICAL AND SUBCLINICAL FEATURES OF BLADDER CANCER IN K HOSPITAL

Purpose: To study clinical and subclinical features of bladder cancer patients. Objects and methods: An uncontrolled clinical intervention study was conducted on bladder cancer patients who had a total bladder resection at $\mathrm{K}$ Hospital. Results: Almost patients were men between the ages of $50-70 ; 14$ patients had a history of laparoscopy to remove tumors and partial bladder surgery, of which 2 patients had a history of laparoscopic surgery to remove the tumor and then the bladdectomy 
partially; $77.4 \%$ of patients receiving cystoscopic surgery diagnosed the preoperative period. Risk factors were addicted to tobacco $(80.6 \%)$ and alcoholism (64.5\%). Hematurine is principal clinical features $80,6 \%$.Total urine analysis: $90.3 \%$ have erythrocytes, $71 \%$ have leukocytes, and $71 \%$ have proteinuria. Almost patients have solitary tumor lesions 61.3\%; tumour size $3-5 \mathrm{~cm}$. Patients have many tumours 29\%; the lateral and posterior walls are equal to $22.6 \% ; 16.1 \%$ anterior wall and $9,7 \%$ tumors caused compression of the ureteral hole causing kidney dilatation. Patients were T2 58.2\%, T3 $19.4 \%$ and T4 $6.5 \%$. Almost patients are in stage II $77,4 \%$. Pathology is transitional carcinoma $96.8 \%$. Conclusion: Bladder cancer is a malignancy more common in men than in women, smoking and alcoholism are possible high risk factors. Hematurine is principal clinical features. Pathology is transitional carcinoma $96.8 \%$.

Keywords: Bladder cancer.

\section{I. ĐẶT VẤN ĐỀ}

Trong hệ tiết niệu, bàng quang là cơ quan có chức năng chứa, điều hòa bài xuất nước tiểu và có ảnh hưởng lớn tới chất lượng cuộc sống [1];[2];[4]. Ung thư bàng quang (UTBQ) là bao gôm ung thư phát triển từ mô bàng quang. Thể bênh UTBQ hay gặp nhất là ung thư tế bào chuyển tiếp chiếm $90-94 \%$, còn lại $5-10 \%$ là các thể bệnh ung thư khác bao gồm: ung thư tế bào vẩy, ung thư biểu mô tuyến, ung thư tổ chức liên kết, ung thư thần kinh nội tiết như ung thư tế bào nhỏ, ung thư tế bào ưa Crom ngoài tủy thượng thận, Melanoma hoặc ung thư di căn từ nơi khác đển [1][3].Theo số liệu thống kê của Bray F.(Globocan 2018), tại Việt Nam, UTBQ đứng hàng thứ hai trong số các ung thư hệ tiết niệu. Mỗi năm có 1502 ca mới mắc và 883 ca tử vong do UTBQ[1]. UTBQ có thể chẩn đoán sớm dựa vào lâm sàng và các công cụ chẩn đoán hình ảnh hiện đại như siêu âm, cắt lớp vi tính, nội soi bàng quang. Chẩn đoán UTBQ sớm dựa vào các dấu hiệu lâm sàng và cận lâm sàng góp phần quan trọng trong việc nâng cao khả năng phẫu thuật triệt căn và tiên lượng điều trị khỏi bệnh[5],[6];[7],[8]. Chúng tôi tiến hành nghiên cứu này với mục tiêu: Nghiên cứu đặc điểm lâm sàng, cận lâm sàng của bệnh nhân ung thư bàng quang.

\section{II. ĐỐI TƯợNG VÀ PHƯƠNG PHÁP NGHIÊN CứU}

2.1. Đối tượng nghiên cứu: các bệnh nhân ung thư biểu mổ bàng quang đã được phẫu thuật cắt bàng quang toàn bộ và chuyển lưu dòng tiểu theo phương pháp Bricker tại Bệnh viện $K$, thời gian từ tháng $1 / 2018$ đến 03/2020.

\section{a. Tiêu chuẩn lứa chọn bênh nhân} - Tuổi từ 18 đến 75.
- Ung thư biểu mô bàng quang: giai đoạn $\mathrm{cT} 2, \mathrm{~T} 3, \mathrm{~T} 4 \mathrm{a}$.

- Được phẫu thuật cắt bàng quang toàn bộ triệt căn và chuyển lưu dòng tiểu theo phương pháp Bricker.

- Có đủ hồ sơ lưu trữ sau phẫu thuật.

\section{b. Tiêu chuẩn loại trừ}

- Ung thư biểu mô bàng quang giai đoạn T4b.

- Khối u khác tại bàng quang: sarcoma, ung thư di căn bàng quang....

- Các bệnh nhân đã có di căn xa.

- Bệnh nhân không đồng ý tham gia nghiên cứu. Bệnh nhân không đủ hồ sơ để phân tích nghiên cứu.

2.2 Phương pháp nghiên cứu: Nghiên cứu can thiệp lâm sàng không đối chứng

\section{KẾT QUẢ NGHIÊN CỨU}

- Nam 90,3\%- Nũ̃ 9.7\%

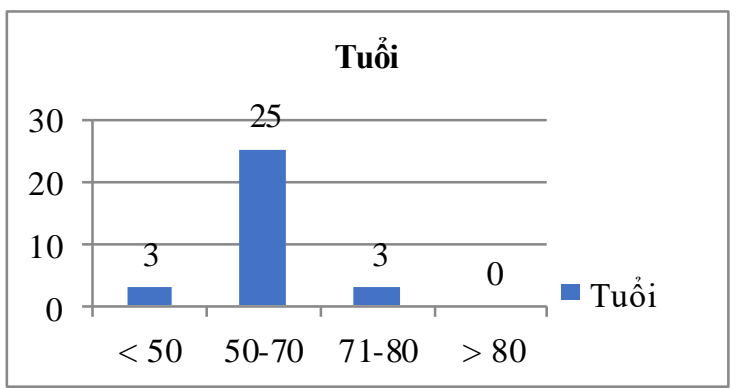

Biểu đồ 3.1: Phân bố bênh nhân theo nhóm tuổi

Nhận xét: nhóm tuổi hay gặp nhất 50-70 tuổi

Bảng 3.1. Tiên sử các bệnh khác và các yếu tố liên quan

\begin{tabular}{|c|c|c|}
\hline & $\begin{array}{c}\text { Số bệnh } \\
\text { nhẩn } \\
\text { (n=31) }\end{array}$ & $\begin{array}{c}\text { Tỉ lệ } \\
\text { \% }\end{array}$ \\
\hline Hút thuốc lá $\geq 5$ năm & 25 & 80,6 \\
\hline Nghiện rượu & 20 & 64,5 \\
\hline Tăng huyết áp & 4 & 12,9 \\
\hline Đái tháo đường & 2 & 6,5 \\
\hline Mố nội soi cắt u phì đại TLT & 0 & 0 \\
\hline Mố nội soi tán sỏi bàng quang & 0 & 0 \\
\hline Mố thoát vị bẽn & 0 & 0 \\
\hline Nhồi máu não & 1 & 3,2 \\
\hline Rò hậu môn & 1 & 3,2 \\
\hline Suy tim & 1 & 3,2 \\
\hline
\end{tabular}

Nhận xét: rượu và thuốc lá là 2 yếu tố nguy cơ cao nhất

Bảng 3.2. Các triệu chứng lâm sàng $(n=31)$

\begin{tabular}{|c|c|c|}
\hline Triệu chứng & Số bệnh nhân & Tỷ lệ (\%) \\
\hline Khám định kì & 3 & 9,7 \\
\hline Đái máu & 25 & 80,6 \\
\hline Đái buốt, rắt & 1 & 3,2 \\
\hline Đau hạ vị & 4 & 12,9 \\
\hline
\end{tabular}




\begin{tabular}{|c|c|c|}
\hline Đái khó, bí đái & 0 & 0 \\
\hline Thiếu máu & 6 & 19,4 \\
\hline \multicolumn{3}{|c|}{$\begin{array}{l}\text { Nhân xét: đái máu là triệu chứng hay gặp nhất } \\
\text { Bảng 3.3. Thởi gian tư lúc có triệu } \\
\text { chứng đầu tiên đến lúc nhập viện(n=31) }\end{array}$} \\
\hline Thời gian (tuânn) & Số bệnh nhân & Tỷ lệ (\%) \\
\hline Khống có TC & 3 & 9,7 \\
\hline$<1$ & 0 & 0 \\
\hline $1-3$ & 3 & 9,7 \\
\hline $3-12$ & 23 & 74,2 \\
\hline$>12$ & 2 & 6,4 \\
\hline Tống & 31 & 100 \\
\hline
\end{tabular}

Nhận xét: bệnh nhân nhập viện chủ yễu

trong vòng 3-12 tháng sau khi có triêu chứng

Bảng 3.4. Các thông số xét nghiệm về công thức máu trước phẫu thuật

\begin{tabular}{|c|c|c|c|c|c|c|}
\hline \multicolumn{2}{|c|}{ Xét nghiệm } & Số BN & Tỷ lệ & Min & Max & ${ }^{\wedge} \pm \mathrm{SD}$ \\
\hline Bạch câu (G/l) & Bình thường & 26 & $\frac{83,9}{161}$ & 3,5 & 14,0 & $7,87 \pm 2,26$ \\
\hline & $\begin{array}{l}\text { Cao > 10G/L } \\
\text { Bình thương }\end{array}$ & $\frac{5}{30}$ & $\frac{16,1}{96,8}$ & & & \\
\hline Hồng câu ( $T / I)$ & Thấp < $3 \mathrm{~T} / \mathrm{L}$ & $\frac{30}{1}$ & 3,2 & 2,94 & 5,2 & $4,07 \pm 0,59$ \\
\hline $\begin{array}{l}\text { Huyết sắc tố } \\
(\mathrm{g} / \mathrm{l})\end{array}$ & $\frac{\text { Bình thường }}{\text { Thấp }<100 \mathrm{~g} / \mathrm{L}}$ & $\frac{29}{2}$ & $\frac{93,6}{6,4}$ & 95 & 152 & $125,6 \pm 16,19$ \\
\hline
\end{tabular}

Nhận xét: phần lớn bệnh nhân không thiếu máu

$\begin{gathered}\text { Bảng 3.6. Các thông số xét nghiệm nước } \\
\text { tiểu trước môô }\end{gathered}$
\begin{tabular}{|c|c|c|}
\hline $\begin{array}{c}\text { Các thông số tiết } \\
\text { niệu }\end{array}$ & $\begin{array}{c}\text { Số beênhh } \\
\text { nhẩn }\end{array}$ & $\begin{array}{c}\text { Tỷ lệ } \\
(\%)\end{array}$ \\
\hline Hồng cẩu niệu & 28 & 90,3 \\
\hline Bạch cầu niệu & 22 & 71,0 \\
\hline Protein niệu & 22 & 71,0 \\
\hline
\end{tabular}

Nhận xét: xét nghiệm nước tiếu thường có hồng cầu

Bảng 3.7. Đặc điểm hình thái u trên CT

\begin{tabular}{|c|c|c|c|}
\hline Đặc điếm u & & $\mathbf{n}$ & $\mathbf{\%}$ \\
\hline \multirow{2}{*}{ Số lượng } & $1 \mathrm{u}$ & 19 & 61,3 \\
\cline { 2 - 4 } & Nhiều u & 12 & 38,7 \\
\hline \multirow{3}{*}{ Kích thước } & $<3 \mathrm{~cm}$ & 10 & 32,3 \\
\cline { 2 - 4 } & $3-5 \mathrm{~cm}$ & 13 & 41,9 \\
\cline { 2 - 4 } & $>5 \mathrm{~cm}$ & 8 & 25,8 \\
\hline \multirow{4}{*}{ Vị trí } & Thành trước & 5 & 16,1 \\
\cline { 2 - 4 } & Thành bên & 7 & 22,6 \\
\cline { 2 - 4 } & Thành sau & 7 & 22,6 \\
\cline { 2 - 4 } & $\begin{array}{c}\text { Lố niệu quản } \\
\text { gây giãn thận }\end{array}$ & 3 & 9,7 \\
\cline { 2 - 4 } & Nhiều vị trí & 9 & 29,0 \\
\hline
\end{tabular}

Nhận xét: chụp CT chủ yếu có 1 u và kích thước từ 3-5cm

Bảng 3.8. Đánh giá giai đoạn bệnh trên CT trước điều trị

\begin{tabular}{|c|c|c|c|}
\hline \multicolumn{2}{|c|}{ CT Scanner ố bụng } & $\mathbf{n}$ & $\%$ \\
\hline $\begin{array}{c}\text { Dánh giá xâm } \\
\text { lấn u nguyên } \\
\text { phát }(\mathrm{T})\end{array}$ & $\begin{array}{c}\text { CLVT không ghi } \\
\text { nhận xâm lấn cơ }\end{array}$ & 5 & 16,1 \\
\cline { 2 - 5 } & T2 & 18 & 58,2 \\
\hline
\end{tabular}

đầu tiên.

Bảng 3.5. Các thông số xét nghiệm sinh hoá máu đánh giá chức năng thận

\begin{tabular}{|c|c|c|}
\hline Chỉ số XN Loại XN & Số BN & Tỷ lệ \% \\
\hline $\begin{array}{c}\text { Bình thường (Ure<8,3 } \\
\text { mmol/L) }\end{array}$ & 28 & 90,3 \\
\hline Cao (Ure $\geq 8,3$ mmol/L) & 3 & 9,7 \\
\hline $\begin{array}{c}\text { Bình thường } \\
\text { (Creatinin <110 mmol/L) }\end{array}$ & 27 & 87,1 \\
\hline $\begin{array}{c}\text { Cao (Creatinin } \geq 110 \\
\text { mmol/L) }\end{array}$ & 4 & 12,9 \\
\hline
\end{tabular}

Nhận xét: phần lớn chức năng thận trong giới hạn bình thường

\begin{tabular}{|c|c|c|c|}
\hline \multirow{4}{*}{$\begin{array}{l}\text { Đánh giá tình } \\
\text { trạng hach } \\
\text { vùng }(\mathrm{N})\end{array}$} & T3 & 6 & 19,4 \\
\hline & $\mathrm{T4}$ & 2 & 6,5 \\
\hline & NO & 31 & 100 \\
\hline & N1 & 0 & 0 \\
\hline \multirow{2}{*}{$\begin{array}{l}\text { Giai đoạn } \\
\text { bệnh }\end{array}$} & $\begin{array}{l}\text { Không đánh giá } \\
\text { giai đoạn trênn } \\
\text { CLVTT }\end{array}$ & 5 & 16,1 \\
\hline & $\begin{array}{l}\text { Giai đoạn II } \\
\text { Giai đoan III }\end{array}$ & $\frac{24}{2}$ & $\begin{array}{c}77,4 \\
6,5\end{array}$ \\
\hline
\end{tabular}

Nhận xét: kết quả giải phẫu bệnh trước mô ung thư biểu mô chuyển tiếp $96,8 \%$; ung thư biểu mô vảy $3,2 \%$.

\section{BÀN LUẬN}

\section{1. Đắc điểm chung}

- Tuổi bệnh nhân: Nghiên cứu của chúng tôi có 31 bệnh nhân UTBQ tuổi trung bình là $61,87 \pm$ 7,27 ; thấp nhất là 43 , cao nhất là 76 , gặp nhiều nhất ở độ tuổi 50-70 (80,6\%). Độ tuổi mắc bệnh trong nghiên cứu của chúng tôi cao hơn so với nghiên cứu Nguyễn Kỳ và tương đương với tác giả Trần Quán Anh, Hinotsu Shiro [2].

- Giới: Trong nghiên cứu của chúng tôi đa phần là nam giới $(90,3 \%)$, tỷ lệ mắc bệnh nam/nữ là $9,3 / 1$. Tî lệ mắc bệnh theo giới của chúng tôi tương đương với các tác giả khác tại Việt Nam nhưng cao hơn các tác giả nước ngoài: Nguyễn Kỳ, De Braud $F$, Andius, Nieder Alan M [5]. Sự khác biệt về tỉ lệ giới tính ở trên có thể do 
tỉ lê hút thuốc lá ở nam và nữ của Viêt Nam rất chểnh lệch chủ yếu là nam giới hút thuốc nhưng ở các nước khác tỉ lệ nữ giới hút thuốc lá cao hơn dẫn tới nguy cơ mắc bệnh ở nữ giới cũng tăng.

- Tiền sử bản thân: Đa số các bệnh nhân trong nghiên cứu của chúng tôi có hút thuốc lá trên 5 năm $(80,6 \%)$ và nghiện rượu $(64,5 \%)$. Các nghiên cứu trên thế giới đã chỉ ra ảnh hưởng của thuốc lá làm gia tăng đáng kể tỉ lệ UTBQ như tác giả Sternberg Corra N (2003)[7] cho rằng UTBQ có liên quan đến thuốc lá và các nghề thường xuyên tiếp xúc với hóa chất.

- Tiền sử điều trị ung thư bàng quang:

Trong nghiên cứu của chúng tôi, nhiều bệnh nhân UTBQ là u tái phát chiếm $14 / 31 \mathrm{BN}$, trong đó12/31 BN đã mổ cắt u nội soi, có $2 / 31 \mathrm{BN}$ tái phát sau phẫu thuật cắt u nội soi nhiêu lần và mổ mở cắt bán phần $\mathrm{BQ}$. Đánh giá chính xác giai đoạn UTBQ xâm lấn cơ bằng phẫu thuật mổ nội soi chẩn đoán trước mổ rất quan trọng giúp đưa ra chiến lược điều trị phù hợp, tránh chỉ định phẫu thuật nội soi nhiều lần hoặc phẫu thuật cắt bàng quang bán phần trước đó, hơn nữa phẫu thuật cắt bàng quan toàn bộ trên những bệnh nhân tái phát sau cắt bàng quang bán phần khó khăn hơn. Nghiên cứu của chúng tôi tương đương với Hoàng Minh Đức và cộng sự [3].

4.2. Các triệu chứng lâm sàng và cận lâm sàng UTBQ xâm lấn

4.2.1. Các triệu chứng lâm sàng UTBQ xâm lấn

- Đái máu: Đái máu là triệu chứng điển hình và khá đặc hiệu đối với UTBQ giai đoạn xâm lấn. Nghiên cứu cho thấy $80,6 \%$ (25/31 BN) vào viện với lý do đái máu, trong đó $100 \%$ đái máu toàn bãi, thậm chí có những bệnh nhân nhiều máu đông, máu cuc trong bàng quang phải soi bơm rửa lấy hết máu cục mới phát hiện được vị trí và kích thước u. Nhiều tác giả như Nguyễn Kỳ (1991), MarvicarA. D. (2000) [6]... cũng xác định từ $80-90 \%$ bệnh nhân UTBQ có đái máu đại thể hoặc vi thể.

- Các triệu chứng tiết niệu khác: ngoài triệu chứng đái máu, có 4 bệnh nhân vào viện vì triệu chứng đau hạ vị; 1 bệnh nhân có tình trạng đái buốt, đái rắt. Tuy nhiên khi xét nghiệm nước tiểu đa phần các bệnh nhân này đều có rối loạn tổng phân tích nước tiểu nghi ngờ như có hồng cầu niệu và chụp cắt lớp vi tính (CLVT) phát hiện u bàng quang.

- 3 bệnh nhân vào viện không có triệu chứng lâm sàng mà do phát hiện u tái phát khi khám định kì kiểm tra sức khỏe. Như vâyy, với các bênh nhân UTBQ nông, việc theo dõi định kỳ sau phẫu thuật nội soi rất quan trọng giúp phát hiện sớm các tổn thương tái phát và điều trị kịp thời[8].

\subsubsection{Thời gian xuât hiện triệu chứng.} Đa số các bệnh nhân đến viện trong vòng 3-12 tuần sau khi có các triệu chứng lâm sàng (74,2\%). Tương đương với tác giả Hoàng Minh Đức và cộng sự [7].

\subsubsection{Triệu chứng toàn thân}

Thiếu máu: UTBQ giai đoạn khu trú thường ít khi có biểu hiện rối loạn toàn thân. Tuy nhiên, với các bệnh nhân đái máu vi thể hoặc đại thể kéo dài có thể dẫn đến biểu hiện thiếu máu hồng câu nhỏ trên lâm sàng và xét nghiệm [5],[6],[7]. Thiếu máu thường ở mức độ nhẹ/vừa và thường không gây ảnh hưởng đến chất lượng cuộc sống hoặc chỉ định phẫu thuật của người bệnh. Nghiên cứu của chúng tôi, tỷ lệ thiếu máu gặp 19,4\% (6/31 bệnh nhân), phần lớn là thiếu máu nhẹ hoặc vừa. Có 2 bệnh nhân thiếu máu nặng do bị tiểu máu đại thể tạo máu cục trong bàng quang phải bơm rửa bàng quang và điều trị kháng sinh cầm máu nội khoa trước mổ.

Gày sút cân: Trong nhóm bệnh nhân nghiên cứu của chúng tôi, có $3 / 31$ bệnh nhân $(9,7 \%)$ trong tình trạng gầy suy kiệt với chỉ số BMI $<18$.

4.2.4. Phẩu thuật nội soi cắt $u$ chẩn đoán giải phẫu bệnh. 77,4\% (24/31) bệnh nhân trong nghiên cứu được chẩn đoán xác định UTBQ xâm lấn cơ qua phẩu thuật nội soi trước mổ cắt bàng quang toàn bộ. Có $8 / 31$ trường hợp đã được chẩn đoán xác định giải phẫu bệnh ung thư tuyến bàng quang qua nội soi bàng quang và chụp CLVT có ghi nhận tình trạng u xâm lấn ở giai đoạn T3, T4. Tuy nhiên 01 bệnh nhân trong nghiên cứu đã được phẫu thuật cắt bàng quang bán phần làm ảnh hưởng đến đánh giá tình trạng xâm lấn trên CLVT nên chúng tôi vẫn tiến hành phẫu thuật nội soi cho bệnh nhân.

\subsubsection{Các chỉ số xét nghiệm máu}

- Công thức máu: Trong nghiên cứu của chúng tôi có 1 trường hợp hồng cầu thấp < 3 $\mathrm{T} / \mathrm{L}$,chiếm $3,2 \%$; 2 trường hợp huyết sắc tố thấp $<100 \mathrm{~g} / \mathrm{L}$, chiếm 6,5\%. Nguyên nhân gây ra tình trạng này là do bênh lý của UTBQ giai đoạn muộn, bệnh nhân đái máu tái phát nhiều lần trong một thời gian dài, gây nên mất máu. Điều này khác với ung thư bàng quang nông, đái máu vi thể hoặc đái máu ra ít một, nên các xét nghiệm công thức máu không hoăc biểu hiên thiếu máu nhẹ. Trong UTBQ, bệnh nhân có thể kèm theo tình trạng viêm nhiễm do ứ đọng nước tiểu. Nghiên cứu chỉ ra có $5 / 31$ bệnh nhân $(16,1 \%)$ có xét nghiệm BC tăng cao > 10G/L. Tuy nhiên việc có kèm theo tình trạng viêm bàng 
quang thường làm cho người làm lâm sàng bỏ sót những trường hợp UTBQ thay vào đó họ không chỉ định phầu thuật mà điều trị nội.

- Sinh hóa máu đánh giá chức năng thân: Nghiên cứu của chúng tôi có $3 / 31$ bệnh nhân $(9,7 \%)$ có urê cao trên $8,3 \mathrm{mmol} / \mathrm{L}, 4 / 31 \mathrm{BN}$ có creatinin cao trên $110 \mu \mathrm{mol} / \mathrm{L}$. Điêu này thường do những trường hợp UTBQ giai đoạn muộn, xâm lấn lỗ niệu quản thường gây ứ đọng nước tiểu ở trên. Hậu quả của quá trình chèn ép này dẫn tới giãn thận và cuối cùng suy thận.

4.2.6. Chup cắt lớp vi tính ổ bung. Chup CLVT ổ bụng trong UTBQ xâm lấn có một giá trị đặc biệt để xác định hình ảnh khối u, kích thước u và đánh giá mức độ xâm lấn sâu vào thành bàng quang hay u xâm lấn ra ngoài thành bàng quang và di căn xa hơn vào các hạch, gan, phổi [7],[8]. Trong nghiên cứu của chúng tôi,trên hình ảnh CLVT ổ bụng, 31/31 bệnh nhân ghi nhận có khối u sùi hoặc lồi vào lòng bàng quang dạng nấm, $3 / 31$ BN có hình ảnh u xâm lấn gây chít hẹp lố niệu quản 2 bên và 1 bên, làm giãn đài bể thân và niêu quản. Về số lượng $u$, có 19 bênh nhân ghi nhận u đơn độc và 12 bênh nhân có nhiêu u. Kích thước u từ 3-5 cm gặp nhiều nhất chiếm $13 / 31$ bệnh nhân; kích thước u dưới $3 \mathrm{~cm}$ gặp ở 10/31 bệnh nhân và $>5 \mathrm{~cm}$ gặp ở 8/31 bệnh nhân.

Kết quả đọc phim CLVT thấy:18/31 bệnh nhân $(58,2 \%)$ u đã xâm lấn tới thành bàng quang chưa ra tới thanh mạc bàng quang (giai đoạn T2). Tất cả các trường hợp này chúng tôi tiến hành phẫu thuật nội soi chẩn đoán xác định tình trạng xâm lấn cơ. $6 / 31$ bệnh nhân $(19,4 \%)$ u xâm ra lớp thanh mac bàng quang vào lớp mõ xung quanh bàng quang (giai đoạn T3), 2/31 bệnh nhân $(6,5 \%)$ u xâm lấn tiền liệt tuyến/túi tinh (giai đoan T4) và có $5 / 31 \mathrm{BN}(16,1 \%)$ không ghi nhân được tình trạng xâm lấn do khối u đã được phẫu thuật nội soi trước đó và một số bệnh nhân có chảy máu bàng quang gây viêm dày thành bàng quang khó xác định được tình trạng xâm lấn qua CLVT, tuy nhiên sau đó những trường hợp này đã được khẳng định lại tình trạng xâm lấn bằng phẫu thuật nội soi chẩn đoán.

4.2.7. Soi bàng quang và sinh thiêt chẩn đoán giải phẩu bệnh: Nghiên cứu của chúng tôi có 24/31 bệnh nhân (77,4\%) được phẫu thuật nội soi bàng quang chẩn đoán, nhằm xác định chính xác giai đoan bênh. Chúng tôi thu được kết quả 5 bệnh nhân không xác định xâm lấn cơ trên chẩn đoán hình ảnh khi phẩu thuật nội soi chẩn đoán đều cho kết quả xâm lấn cớ. Như vậy, 100\% bệnh nhân được phát hiện ra u, đa số bệnh nhân u có tính chất sùi vào trong lòng bàng quang và dễ chảy máu, u ở nhiều vị trí (29\%), vùng lỗ niệu quản gây giãn thận $(9,7 \%)$, thành trước $(16,1 \%)$, thành bền $(22,6 \%)$, thành sau $(22,6 \%)$.

4.2.8. Giải phâuu bệnh: Tất cả các bệnh phẩm sau nội soi sinh thiết và phẫu thuật đều được chuyển tới làm tiêu bản, phân tích và trả lời tại khoa giải phẫu bênh bênh viện K.Hầu hết các bệnh nhân có thể giải phấu bệnh là ung thư biểu mô chuyển tiếp $96,8 \%$ chỉ có $3,2 \%$ bênh nhân ung thư biểu mô vảy và không có bệnh nhân nào ung thư biểu mô tuyến. Theo y văn, UTBQ có từ 90-95\% là ung thư tế bào chuyển tiếp đường tiết niêu (Transition cell carcinoma - TCC), còn lai 2 $7 \%$ là ung thư dạng tuyến và ung thư tế bào vảy (Squamous cell carcinoma - SCC) [2],[6].... Kết quả nghiên cứu của chúng tôi cũng phù hợp với các nghiên cứu trong và ngoài nước.

\section{KẾT LUÂN}

Ung thư bàng quang hay găp ở nam hơn ở nữ, hút thuốc lá và nghiện rượu là yếu tố nguy cơ cao, đái máu là dấu hiệu lâm sàng phổ biến, có thể phát hiện sớm bằng những phương tiện chẩn đoán như siêu âm, chụp cắt lớp vi tính, nội soi bàng quang. Giải phẫu bệnh chủ yếu là ung thư biểu mô chuyển tiếp.

\section{TÀI LIÊU THAM KHẢO}

1. Freddie Bray (2018) "Global cancer statistics: GLOBOCAN estimates of incidence and mortality worldwide for 36 cancers in 185 countries". ACS Journals.: pp. 55-65.

2. Hinotsu Shiro (2006) "Sustained prophylactic effect of intravesical bacille Calmette-Guerin for superficial bladder cancer: A smoothed hazard analysis in a randomized prospective study". Urology: pp. 545-549.

3. Hoàng Minh Đức (2012), Đánh giá kết quả phẩu thuật cắt toàn bộ bàng quang và dẫn lưu nước tiểu theo phương pháp Bricker trong điều trị ung thư bàng quang tại bệnh viên Việt Đức. Luận án Bác sĩ Nôi trú, Đại họ Y Y Hà Nồi: pp. 10-50.

4. Nguyễn Văn Hiếu (2010) "Điều trị phẫu thuật bệnh ung thư". Nhà xuất bản Y học.: pp. 411-427.

5. Nieder Alan M.(2005) " Radical cystectomy after bacillus Calmetter-Guerin for high-rick $\mathrm{Ta}, \mathrm{T} 1$, and carcinoma in situ: Defining the rick of initial bladder preservation". Urology: pp. 737-741.

6. Macvicar A.D (2000), Bladder cancer staging BJU International: p. 111 .

7. Sternberg CN (2003) Can patient selection for bladder preservation be based on response to chemotherapy? Cancer: pp. 1644-1652.

8. Raman J.D (2005) Bladder cancer after managing upper urinary tract transition cell carcinoma: predictive factors and pathology. BJU International: p. 1031. 